\title{
Editorial Note: Multimedia Big Data
}

Published online: 29 March 2018

(C) Springer Science+Business Media, LLC, part of Springer Nature 2018

Multimedia Tools and Applications gratefully acknowledges the editorial work of the scholars listed below on the special issue entitled, "Multimedia Big Data."

Of 48 papers submitted to this issue, 26 were eventually accepted after a stringent peer-review process.

Zhigao Zheng (Corresponding Guest Editor)

Huazhong University of Science \& Technology

Wuhan, China

pkuwalter@gmail.com; zhengzhigao@pku.edu.cn

Ford Lumban Gaol

Bina Nusantara University, Indonesia

fgaol@binus.edu

Krishn K. Mishra

Department of Mathematics and Computer Science

University of Missouri, USA

mishrak@umsl.edu 